\title{
Wiek dolnodewońskiego poziomu tufitowego z Barczy (Góry Świętokrzyskie) na podstawie miospor
}

\author{
Anna Fijałkowska-Mader ${ }^{1}$, Jan Malec ${ }^{2}$
}

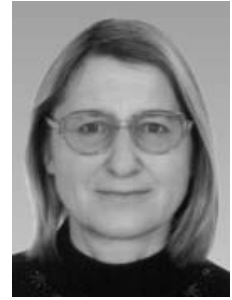

A. Mader

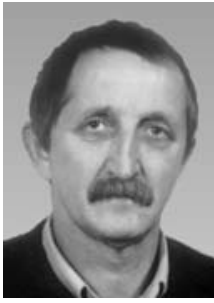

J. Malec
Age of the Lower Devonian tuffite horizon from Barcza (Holy Cross Mountains, S Poland). Prz. Geol., 66: 578-584; doi: 10.7306/2018.8

A b s tra ct. Results of palynological studies of the Lower Devonian siliciclastic deposits of the Barcza Beds (Upper Pragian-Lower Emsian) from two abandoned quarries at Barcza in the Holy Cross Mts. is presented. Based on miospores, the biostratigraphic position of the tuffite horizon from the Barcza profile was defined as the early Emsian AB (annulatus-bellatulus) palynological Zone.

Keywords: palynostratigraphy, tuffite horizon, Lower Devonian, Holy Cross Mountains

Podczas prac badawczych, związanych z inwentaryzacją geostanowisk, uzyskano nowe informacje dotyczące stratygrafii osadów dolnego dewonu, które w regionie łysogórskim Gór Świętokrzyskich odsłaniają się na zachodnim krańcu Pasma Klonowskiego, w nieczynnych kamieniołomach w rejonie Barczy (zobacz zdjęcie na okładce, ryc. 1 i 2A). Na podstawie badań palinologicznych udało się po raz pierwszy określić wiek poziomu tufitowego w profilu stratotypowym warstw barczańskich. Umożliwiło to powiązanie tefrostratygrafii i palinostratygrafii oraz rzuciło nowe światło na korelacje dolnodewońskich poziomów tufitowych w regionie kieleckim i łysogórskim.

Eksploatacja piaskowców dolnego dewonu w rejonie Barczy rozpoczęła się na początku ubiegłego wieku (Czarnocki, 1928a, b, 1936) i trwała do lat 60. Istniało tu kilka kamieniołomów. W 1984 r. na południowo-zachodnim skłonie Góry Barcza utworzono rezerwat przyrody nieożywionej o powierzchni 14,57 ha. W jego obrębie znajdują się dwa kamieniołomy - północny i wschodni (Urban, 1980; Wróblewski, 2000). Poza rezerwatem znajduje się trzeci kamieniołom - południowy (ryc. 2B). Czwarty, największy kamieniołom stanowił w latach 70. i 80. ubiegłego wieku wysypisko śmieci, a po całkowitym wypełnieniu odpadami został zrekultywowany. Obecnie zaznacza się w terenie jako bezleśny obszar porośnięty trawą (ryc. 2B).

\section{HISTORIA BADAŃ I LITOSTRATYGRAFICZNA POZYCJA POZIOMU TUFITOWEGO W REJONIE BARCZY}

Litologiczne następstwo osadów dolnego dewonu w Paśmie Klonowskim w rejonie Barczy po raz pierwszy przedstawił Czarnocki (1919), wyróżniając na tym obszarze kilka charakterystycznych serii skalnych: piaskowiec czerwony (old red), piaskowiec plakodermowy i piaskowiec spiriferowy. Osady dewonu dolnego z tego obszaru były przedmiotem jego dalszych badań w aspekcie litologicznym, stratygraficznym oraz surowcowym (Czarnocki,

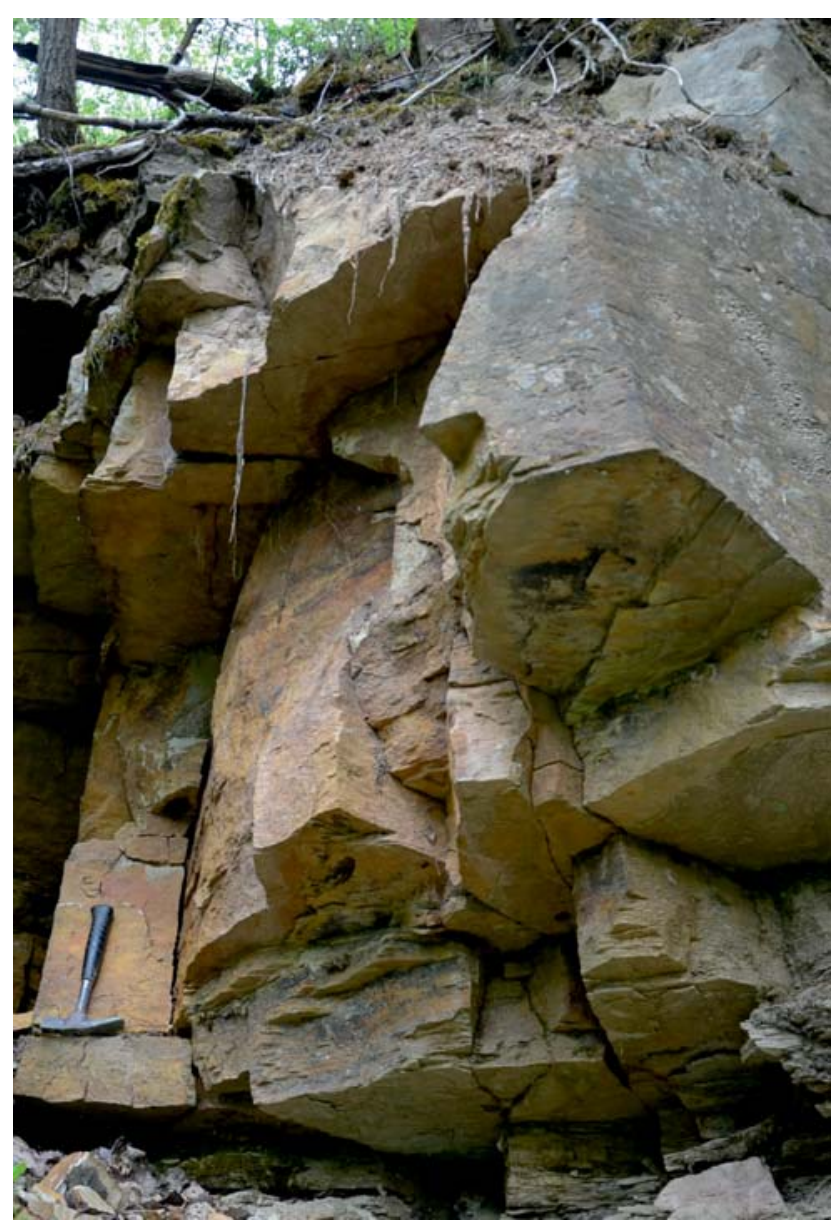

Ryc. 1. Gruba ławica piaskowca, dolny dewon warstwy barczańskie, Barcza, kamieniołom południowy. Fot. J. Malec

Fig. 1. Thick-bedded sandstone, Lower Devonian, Barcza Beds, Barcza, southern quarry. Photo by J. Malec

1928a, b). Następnie Czarnocki (1936) opracował profil litostratygraficzny tych utworów, wyróżniając w nim kolejno: warstwy klonowskie, barczańskie, piaskowce

\footnotetext{
${ }^{1}$ Państwowy Instytut Geologiczny - Państwowy Instytut Badawczy, Oddział Świętokrzyski, ul. Zgoda 21, 25-953 Kielce; anna.mader@pgi.gov.pl.

2 Emerytowany pracownik Państwowego Instytutu Geologicznego - Państwowego Instytutu Badawczego, Oddziału Świętokrzyskiego; jan.malec@pgi.gov.pl.
} 
spiriferowe, piaskowce skolitusowe i piaskowce ciosowe. W ramach arkusza Kielce 1:100 000 wykonał także mape geologiczną zachodniej części Pasma Klonowskiego (Czarnocki, 1938).

W górnej części profilu warstw barczańskich Czarnocki (1936) stwierdził obecność grubej warstwy tufitowej. Ogólną charakterystykę petrograficzną tych tufitów przedstawił Z. Sujkowski (Czarnocki, 1936), a w późniejszym okresie Małkowski (1954). Szczegółowe badania poziomu tufitowego, występującego w kamieniołomie wschodnim, wykonała Kardymowicz (1960a, b), natomiast poziom tufitowy odsłaniający się w kamieniołomie północnym opisali Łobanowski i Michniak (1960). Nowszą propozycję litostratygrafii osadów dolnego dewonu w Paśmie Klonowskim przedstawił Łobanowski (1971). Powyżej warstw barczańskich wyróżnił on warstwy zagórzańskie, odpowiadające

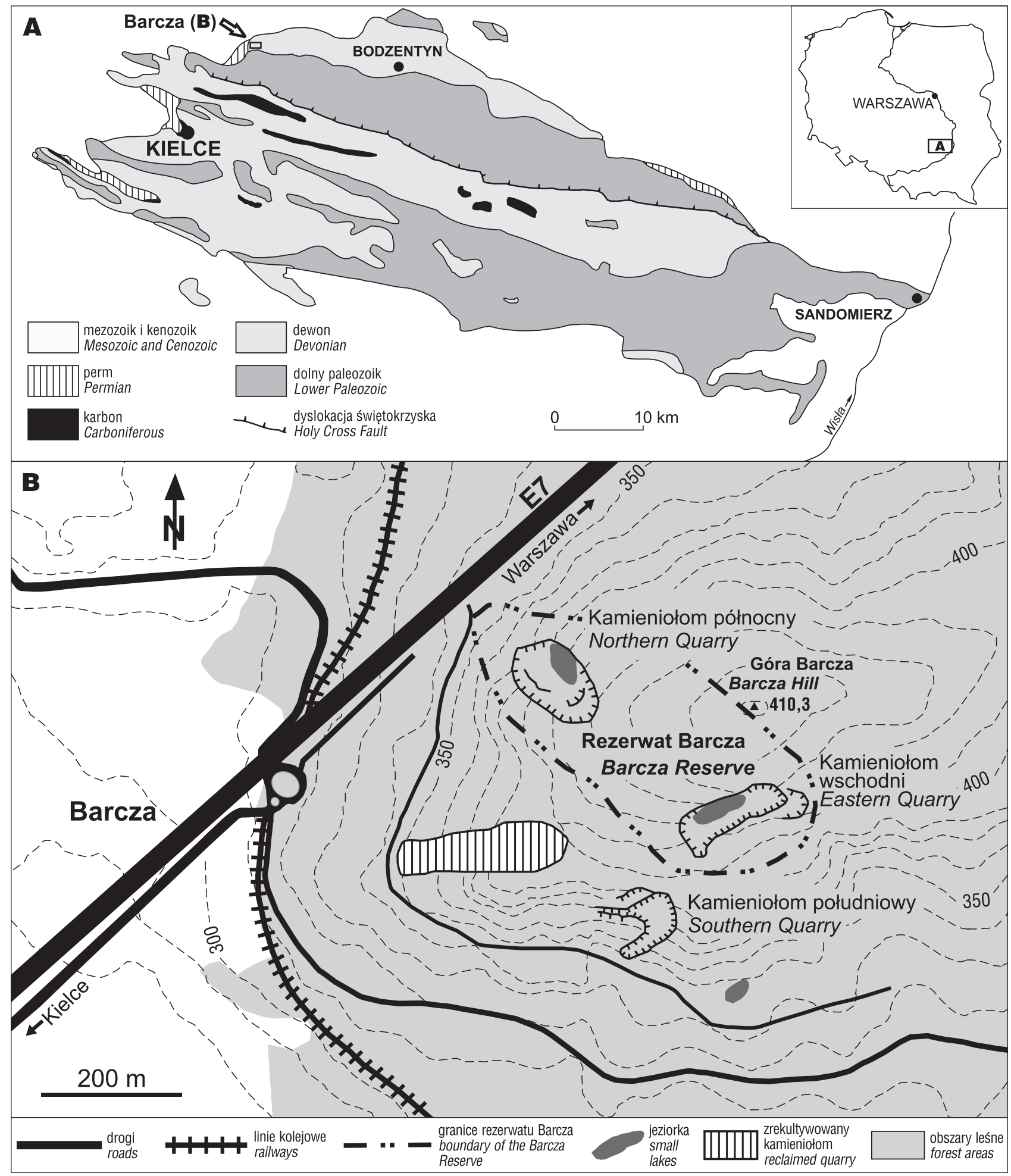

Ryc. 2. A - Lokalizacja obszaru badań na tle uproszczonej mapy geologicznej Gór Świętokrzyskich wg Filonowicza (1961); B - Lokalizacja Barczy z zaznaczonymi kamieniołomami

Fig. 2. A-Location of the study area against the simplified geological map of the Holy Cross Mountains (after Filonowicz, 1961); B - Location of Barcza with marked quarries 


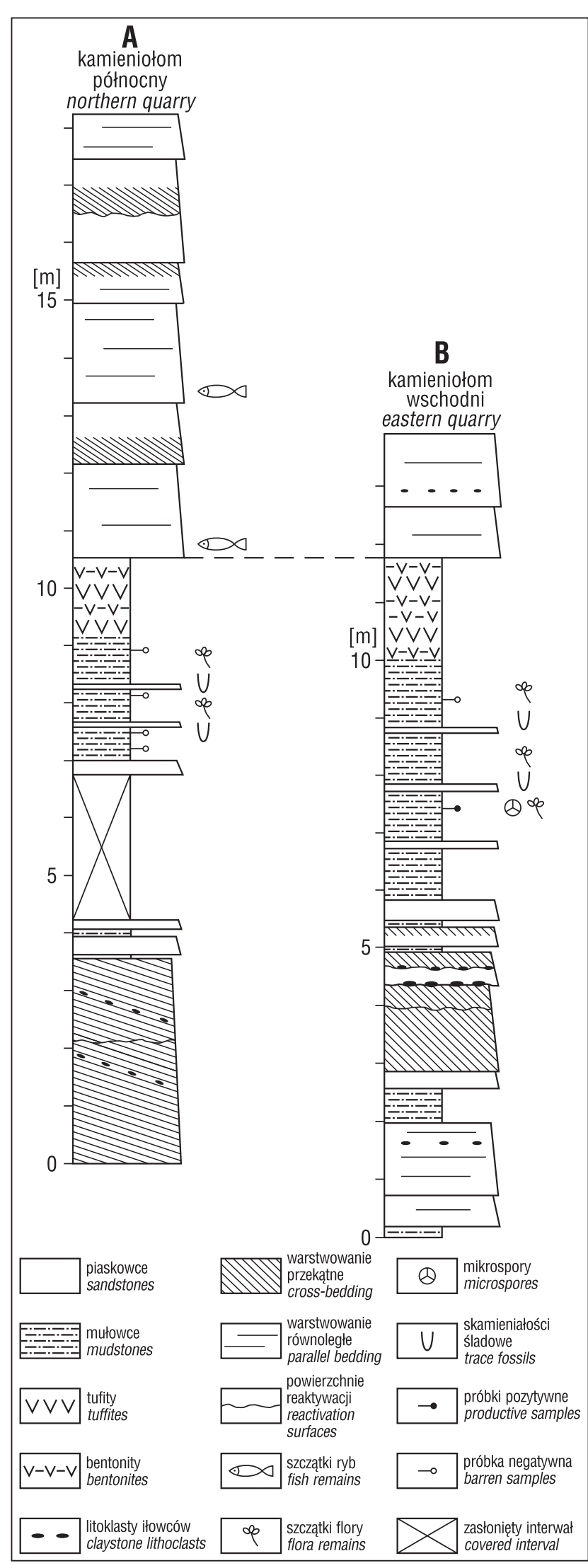

Ryc. 3. Położenie poziomu tufitowego w profilu dolnego dewonu warstw barczańskich: A - w kamieniołomie północnym w Barczy (wschodnia część); B - w kamieniołomie wschodnim (środkowa część). Pozycja szczątków ryb w profilu wg Burrowa i Szreka (2018)

Fig. 3. Location of the tuffite horizon in a Lower Devonian section of the Barcza Beds: A - in the northern quarry at Barcza (eastern part); $\mathbf{B}$ - in the eastern quarry (middle part). Position of fish remains after Burrow and Szrek (2018) piaskowcom spiriferowym, skolitusowym i ciosowym. Później Łobanowski (1981, 1990) wprowadził nieformalne nazwy formacji klonowskej, barczańskiej i zagórzańskiej. Pierwszą z jednostek zaliczył do lochkowu, drugą do pragu i dolnego emsu, a ostatnią - do górnego emsu.

Poziom tufitowy o grubości od 0,7 do $1,5 \mathrm{~m}$, występujący w kamieniołomie północnym i wschodnim, Łobanowski (1981, 1990) wyróżnił jako nową jednostkę litostratygraficzną - ogniwo tufitów z Lubrzanki. Początkowo osady te umiejscowił $\mathrm{w}$ dolnej części warstw zagórzańskich (Łobanowski, 1971), a później - w stropie warstw barczańskich (Łobanowski, 1981, 1990).

Ponieważ wymienione jednostki litostratygraficzne $\mathrm{w}$ randze formacji i ogniw nadal wymagają formalizacji (por. Alexandrowicz i in., 1975; Racki, Narkiewicz, 2006), autorzy w dalszej części artykułu posługują się starszymi nazwami - warstwy barczańskie i warstwy zagórzańskie.

\section{LOKALIZACJA POZIOMÓW TUFITOWYCH W KAMIENIOLOMACH BARCZY}

Poziomy tufitowe, rozpoznane w kamieniołomach północnym i wschodnim, są zlokalizowane w stropowych partiach kompleksów mułowcowo-piaskowcowych, występujących pomiędzy seriami średnio- i gruboławicowych piaskowców kwarcytowych (ryc. 3A, 3B, 4A).

Kompleks mułowcowo-piaskowcowy w północnej ścianie kamieniołomu północnego, o łącznej miąższości od 5 do $7 \mathrm{~m}$, w dolnej części jest złożony z cienko- i średnioławicowych piaskowców i mułowców o barwie brunatnej, a w górnej - z mułowców o barwie szarozielonej z podrzędnym udziałem piaskowców cienkoławicowych, lokalnie zbioturbowanych, ze szczątkami roślin. Górną część kompleksu tworzą osady piroklastyczne o grubości ok. 1,5 m, złożone z kilku 20-25-centymetrowych warstw zwięzłych zielonych tufitów, rozdzielonych warstwami plastycznych zielonych bentonitów o podobnej grubości (ryc. 3A, 4D).

W północnej ścianie kamieniołomu wschodniego, pomiędzy gruboławicowymi piaskowcami kwarcytowymi, występuje kompleks mułowcowo-piaskowcowy o miąższości ok. $6 \mathrm{~m}$, złożony z podobnych osadów jak w kamieniołomie północnym (ryc. $3 \mathrm{~B}$ ). W zielonoszarych mułowcach są obecne rozproszone szczątki roślin oraz warstwy $\mathrm{z}$ bioturbacjami. W górnej części kompleksu, na odcinku ok. 1,5 m, odsłonięto osady piroklastyczne (ryc. 4B, 4C). $\mathrm{W}$ ich dolnej części występują plastyczne bentonity o zielonej barwie. Ponad nimi znajduje się ok. 40-centymetrowa warstwa zwięzłych, zielonoszarych tufitów, a wyżej 65-centymetrowa warstwa plastycznych bentonitów o zielonej barwie, z widoczną miejscami poziomą laminacją. Stropową część osadów piroklastycznych tworzy 30-centymetrowa warstwa zwięzłych, jasnozielonych tufitów o łupkowej teksturze, z widocznymi makroskopowo ziarnami kwarcu i jasnymi, zwietrzałymi skaleniami (ryc. 4B), oraz leżące powyżej zielonoszare bentonity o podobnej grubości.

\section{ZARYS HISTORII BADAŃ PALINOLOGICZNYCH DOLNEGO DEWONU W GÓRACH ŚWIĘTOKRZYSKICH}

Badania mikroflorystyczne osadów dolnego dewonu w regionie kieleckim Gór Świętokrzyskich zapoczątkowała L. Jakubowska w latach 60. XX w. (Jakubowska, 
1968, 1971, 1972, 1974). Ich wynikiem było wyróżnienie dwóch zespołów sporowych: I - w osadach dolnego kompleksu mułowcowego (obecnie warstwy z Haliszki) oraz II - w obrębie górnego kompleksu piaskowcowego (obecnie warstwy z Winnej). Nazwę formacja z Haliszki wprowadziła dla dolnego kompleksu mułowcowego Tarnowska (1995), natomiast dla leżących wyżej w profilu kompleksów: środkowego piaskowcowego, górnego mułowcowego i górnego piaskowcowego - formacja z Winnej, które konsekwentnie stosowała (Tarnowska, 1999), pomimo że, podobnie jak u Łobanowskiego (1981, 1990), nie spełniają one wymogów formalnych jednostek litostratygraficznych. Dlatego też autorzy niniejszego artykułu stosują nazwy warstwy z Haliszki i warstwy z Winnej.

Badania palinologiczne dolnego dewonu w regionach kieleckim i łysogórskim kontynuowali: Turnau (1994, 1995a, b; a także w Malec i in., 1990), Fijałkowska (1995a, b, 1996), Fijałkowska-Mader i in. (1997), Kowalczewski i Turnau (1997), Turnau i Tarnowska (1997), Filipiak (2009, 2011), Fijałkowska-Mader (2010, 2011) oraz Fijałkowska-Mader
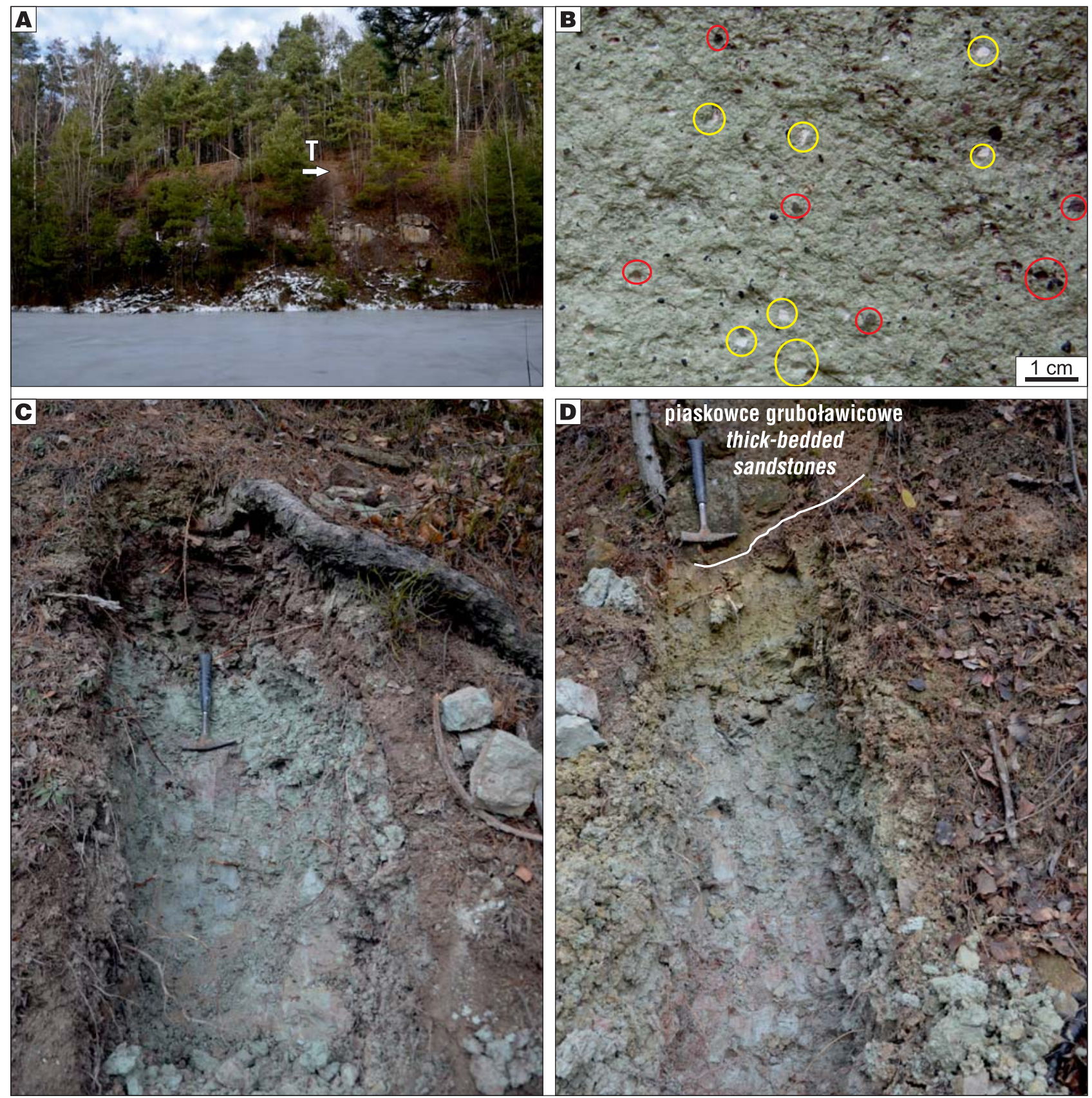

Ryc. 4. Poziomy tufitowe w kamieniołomach wschodnim i północnym w Barczy: A-lokalizacja poziomu tufitowego (T) w północnej ścianie wschodnigo kamieniołomu w Barczy; B - ciemne ziarna kwarcu (obwódki czerwone) i białe zwietrzałe skalenie (obwódki żółte) widoczne na powierzchni warstwy tufitów we wschodnim kamieniołomie w Barczy; C - stropowa część poziomu tufitowego odsłonięta we wschodnim kamieniołomie w Barczy. Młotek jako skala ma długość $28 \mathrm{~cm}$; D - stropowa część poziomu tufitowego odsłonięta w północnym kamieniołomie w Barczy. Wszystkie fot. J. Malec

Fig. 4. Tuffite horizons in the eastern and northern Barcza quarries: $\mathbf{A}$ - location of the tuffite horizon in the northern wall of the eastern Barcza quarry; B - dark quartz grains (red rims) and white, weathered feldspars (yellow rims) visible at the tuffite surface from the eastern Barcza quarry; $\mathbf{C}$ - upper part of the tuffite horizon exposed at the eastern Barcza quarry. Hammer for scale is $28 \mathrm{~cm}$ long; D - upper part of the tuffite horizon exposed at the northern Barcza quarry. All photos by J. Malec 


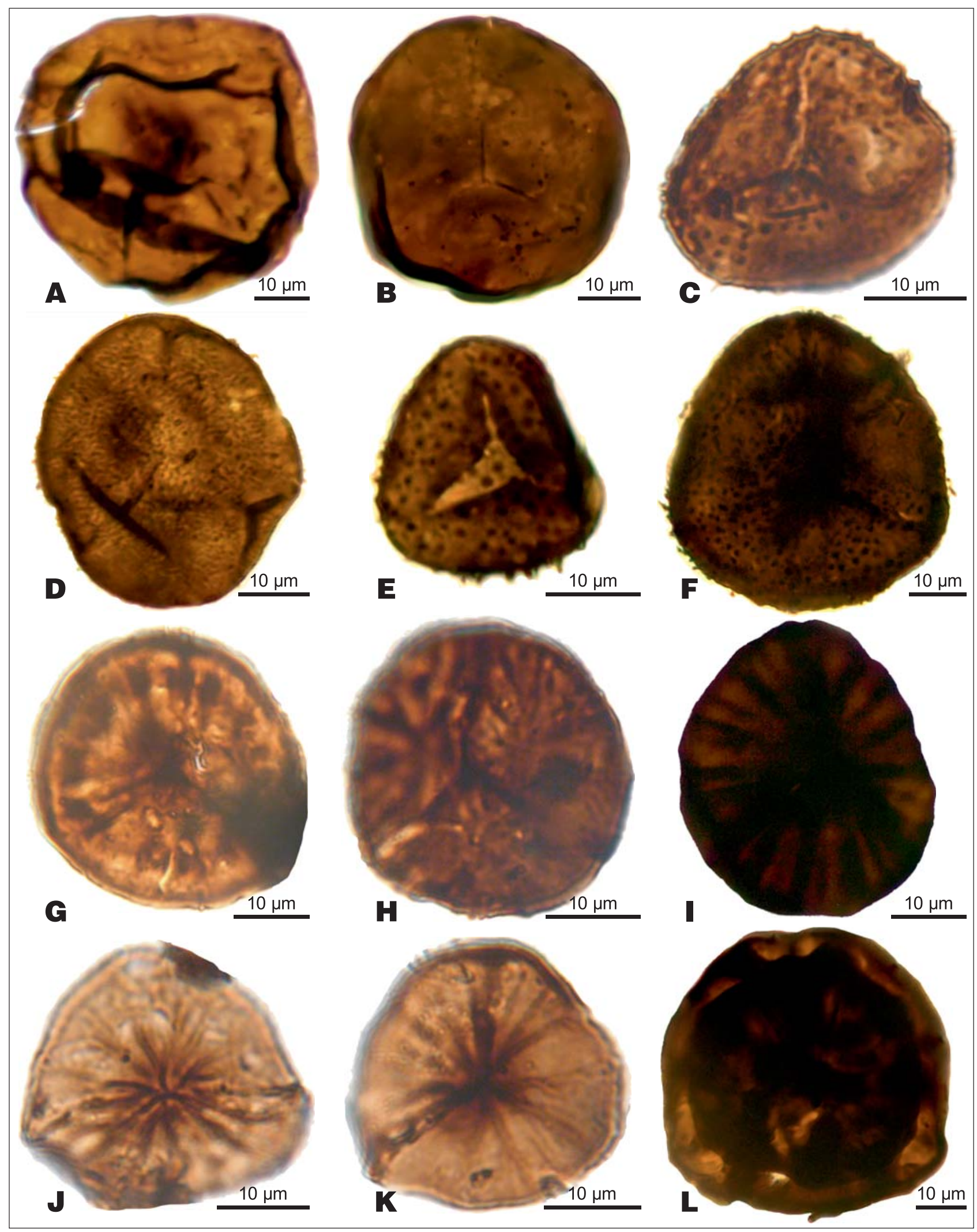

Ryc. 5. Dolnodewońskie spory z kamieniołomu wschodniego Barczy: A-Calamospora atava (Naumova) McGregor, B - Retusotriletes communis Naumova, C - Anapiculatisporites sp., D - Apiculiretusispora plicata (Allen) Streel, $\mathbf{E}$ - Dibolisporites cf. eifeliensis (Lanninger) McGregor, F - Dibolisporites sp., $\mathbf{G}$ - Emphanisporites annulatus McGregor, $\mathbf{H}$ - Emphanisporites schultzii McGregor, $\mathbf{I}$-Emphanisporites cf. erraticus (Eisenack) McGregor, $\mathbf{J}-\mathbf{K}$-Emphanisporites rotatus (McGregor) McGregor, $\mathbf{L}-$ Coronaspora mariae Rodriguez

Fig. 5. The Lower Devonian spores form the eastern Barcza quarry: A-Calamospora atava (Naumova) McGregor, B - Retusotriletes communis Naumova, C - Anapiculatisporites sp., D - Apiculiretusispora plicata (Allen) Streel, E - Dibolisporites cf. eifeliensis (Lanninger) McGregor, $\mathbf{F}$ - Dibolisporites sp., $\mathbf{G}$-Emphanisporites annulatus McGregor, $\mathbf{H}$-Emphanisporites schultzii McGregor, $\mathbf{I}$ - Emphanisporites cf. erraticus (Eisenack) McGregor, $\mathbf{J}-\mathbf{K}-$ Emphanisporites rotatus (McGregor) McGregor, $\mathbf{L}-$ Coronaspora mariae Rodriguez 
i Malec (2011). Na podstawie wyników tych prac możliwe było stwierdzenie poziomu palinologicznego MN w górnej części warstw bostowskich w regionie łysogórskim, wskazującego na wczesny lokchow (por. Streel i in., 1987). Zidentyfikowano także dwa poziomy palinologiczne (PW i AB) w osadach warstw z Barczy i najniższej części warstw zagórzańskich $\mathrm{w}$ regionie łysogórskim oraz $\mathrm{w}$ warstwach z Haliszki w regionie kieleckim, które datują te utwory jako późny prag i wczesny ems (por. Streel i in., 1987). Odpowiadają one zespołowi I wg Jakubowskiej (1974). W wyższej części warstw zagórzańskich i dolnej części formacji grzegorzowickiej (region łysogórski) oraz w stropie warstw z Haliszki i w warstwach z Winnej (region kielecki) wyróżniono dwa poziomy palinologiczne (FD i AP część dolna), które umożliwiają określenie wieku tych osadów jako późny ems (por. Streel i in., 1987). Prawdopodobnie zespół II wyróżniony przez Jakubowską (1974) można korelować z dolną częścią poziomu AP.

\section{WYNIKI BADAŃ MIKROFLORY OSADÓW Z BARCZY I POZYCJA STRATYGRAFICZNA POZIOMÓW TUFITOWYCH}

Do badań palinologicznych pobrano łącznie 6 próbek z kamieniołomów północnego i wschodniego (ryc. 3) - z szarozielonych mułowców leżących poniżej osadów piroklastycznych. Tylko jedna próbka pochodząca z kamieniołomu wschodniego, zlokalizowana w odległości ok. 1,7 m powyżej ławicy średnioławicowych zażelazionych piaskowców, leżących w stropowej części kompleksu piaskowców gruboławicowych, okazała się pozytywna (ryc. 3B). Zawiera ona stosunkowo bogaty zespół, złożony wyłącznie z miospor dolnodewońskich. Dominują w nim przedstawiciele następujących gatunków: Emphanisporites annulatus McGregor (ryc. 5G), Coronaspora mariae Rodriguez (ryc. 5L), Apiculiretusispora plicata (Allen) Streel (ryc. 5D) i Dibolisporites cf. eifeliensis (Lanninger) McGregor (ryc. 5E). Ponadto w zespole licznie spotyka się innych przedstawicieli rodzaju Emphanisporites (ryc. 5H-K), rzadziej rodzaju Dibolisporites (ryc. 5F). Stosunkowo często występują spory z rodzajów Retusotriletes (ryc. 5B) i Calamosora (ryc. 5A), nielicznie natomiast jest reprezentowany rodzaj Anapiculatisporites (ryc. 5C).

Obecność W zespole sporowym przewodniego gatunku Emphanisporites annulatus wskazuje na poziom palinologiczny AB (annulatus-bellatulus). Występowanie w tym zespole spory Coronaspora mariae Rodriguez, o stosunkowo krótkim zasięgu stratygraficznym, lokuje go w wyższej części pozio- mu AB. Wiek poziomu AB jest przyjmowany jako wczesny ems (Streel i in., 1987; Fijałkowska-Mader, Malec, 2011).

Na podstawie udokumentowania obecności spor poziomu AB poniżej poziomu tufitowego można określić jego wiek na wczesny ems. Tego samego wieku jest poziom tufitowy T2 wyróżniony przez Tarnowską (1999) w górnej części warstw z Haliszki w regionie kieleckim Gór Świętokrzyskich i odpowiada on, zdaniem autorów, tufitom z Barczy (ryc. 6). W kamieniołomach Barczy nie odsłania sie starszy poziom tufitowy T1, występujący w dolnej części warstw barczańskich w profilu Tarczek 2 (por. Wróblewski, 1975; Fijałkowska-Mader, 2011).

Brak wskaźnikowych skamieniałości w niższej części warstw barczańskich uniemożliwia określenie pozycji biostratygraficznej najstarszych osadów tej jednostki. Można przypuszczać, że należą one najprawdopodobniej do najniższego emsu i górnego pragu - podobnie jak zbliżone pod względem wykształcenia litologicznego osady najniższego dewonu dolnego, stwierdzone w profilach wiertniczych Modrzewie 4 i Tarczek 2, zlokalizowanych na wschód od Pasma Klonowskiego. W otworach tych udokumentowano obecność palinologicznego poziomu PW

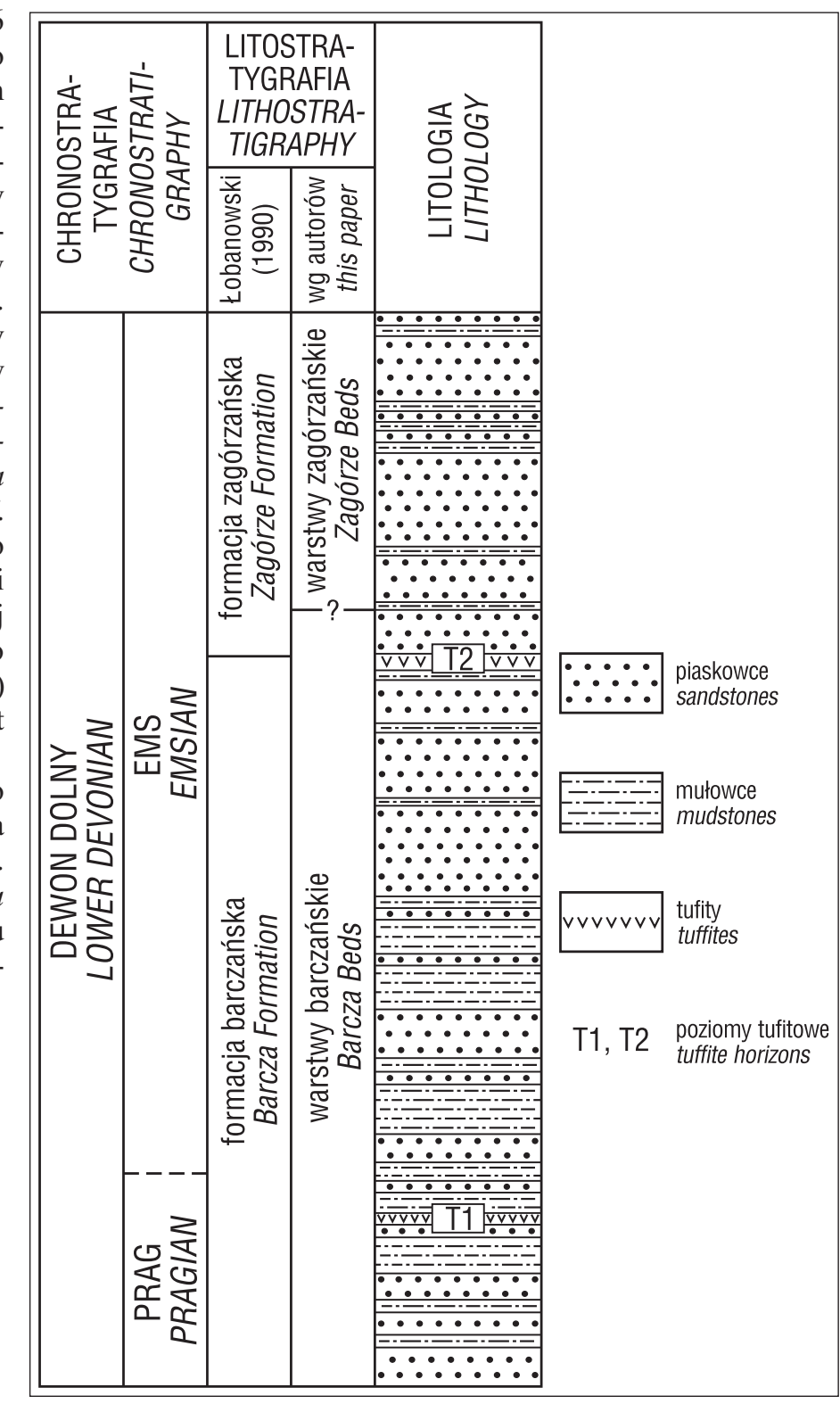

Ryc. 6. Pozycja poziomów tufitowych w profilu litostratygraficznym dolnego dewonu w regionie łysogórskim Gór Świętokrzyskich (wg Fijałkowskiej-Mader, Malca, 2011) Fig. 6. Position of the tuffite horizons in the Lower Devonian lithostratigraphic section of the Lysogóry Region, Holy Cross Mts. (after Fijałkowska-Mader, Malec, 2011) 
(polygonalis-wetteldorfensis), którego wiek jest określany jako prag (Turnau, 1994, 1995a, b; Fijałkowska, 1995b; Fijałkowska-Mader i in., 1997; Kowalczewski, Turnau, 1997; Fijałkowska-Mader, 2010; Fijałkowska-Mader, 2011; Fijałkowska-Mader, Malec, 2011).

Autorzy artykułu składają podziękowania Recenzentom: Profesorowi dr. hab. Zdzisławowi M. Migaszewskiemu i Profesorowi Uniwersytetu Śląskiego, dr. hab. Pawłowi Filipiakowi za cenne uwagi i wskazówki.

\section{LITERATURA}

ALEXANDROWICZ S., BIRKENMAJER K, BURCHART J, CIEŚLIŃSKI S., DADLEZ R., KUTEK J, NOWAK W., OREOWSKI S, SZULCZEWSKI M., TELLER L. 1975 - Zasady polskiej klasyfikacji, terminologii i nomenklatury stratygraficznej. Instrukcje i metody badań geologicznych, 33: 1-63.

BURROW C., SZREK P. 2018 - Acanthodians from the Lower Devonian (Emsian) "Placoderm Sandstone", Holy Cross Mountains, Poland. Acta Geol. Pol., 68 (w druku).

CZARNOCKI J. 1919 - Stratygrafia i tektonika Gór Świętokrzyskich. Pr. Tow. Nauk. Warszaw., 28: 1-172.

CZARNOCKI J. 1928a - Dewon dolny w paśmie Klonowskim. Pos. Nauk. Państw. Inst. Geol., 19/20: 14-16.

CZARNOCKI J. 1928b - W sprawie rozbudowy kamieniołomów państwowych w Zagnańsku. Pos. Nauk. Państw. Inst. Geol., 19/20: 16-22. CZARNOCKI J. 1936 - Przegląd stratygrafii i paleogeografii dewonu dolnego Gór Świętokrzyskich. Spraw. Państw. Inst. Geol., 8: 129-200. CZARNOCKI J. 1938 - Ogólna mapa geologiczna Polski 1:100 000 ark. 4, Kielce. Woj. Inst. Wyd., Warszawa.

FIJAŁKOWSKA A. 1995a - Wyniki badań mikrosporowych w osadach dewonu dolnego z otworów Wszachów 4 i Duża Skała 5 (S czesść Gór Świętokrzyskich). Nar. Arch. Geol., PIG-PIB, Kielce.

FIJAŁKOWSKA A. 1995b - Wyniki badań mikrosporowych w osadach dewonu z otworów Tarczek 1A, Tarczek 1 i Tarczek 2 (region łysogórski Gór Świętokrzyskich). [W:] Malec J. (red.), Korelacje litostratygraficzne, biostratygraficzne i geochemiczne utworów dewonu w Górach Świętokrzyskich. Nar. Arch. Geol., PIG-PIB, Warszawa.

FIJAŁKOWSKA A. 1996 - Badania mikroflorystyczne osadów górnego zigenu i emsu w S części Gór Świętokrzyskich ze szczególnym uwzględnieniem problemu granicy między emsem dolnym i górnym. Nar. Arch. Geol., PIG-PIB, Warszawa.

FIJAŁKOWSKA-MADER A. 2010 - Palynostratigraphy of the Upper Pragian (Siegenian) and Emsian in the southern part of the Holy Cross Mountains (Poland). [W:] Oliwkiewicz-Miklasińska M., Stempień-Sałek M., Łaptaś A. (red.), CIMP Poland 2010, General Meeting, Abstracts: 14 Inst. Nauk Geol. PAN, Warszawa.

FIJAŁKOWSKA-MADER A. 2011 - Palinostratygrafia dewonu dolnego w regionie łysogórskim Gór Świętokrzyskich. [W:] Trela W., Salwa S., Fijałkowska-Mader A. (red), 6. Świętokrzyskie Spotkania Geologiczno-Geomorfologiczne, Ameliówka k. Kielc, 17-18 maja 2011. Mat. Konf.: 18-22. Państw. Inst. Geol.-PIB, Kielce.

FIJAŁKOWSKA-MADER A., MALEC J., TARNOWSKA M., TURNAU E. 1997 - Stratygrafia dolnego dewonu w rejonie Bodzentyna region łysogórski Gór Swiętokrzyskich. Pos. Nauk. Państw. Inst. Geol., 53: $122-125$.

FIJAŁKOWSKA-MADER A., MALEC J. 2011 - Biostratigraphy of the Emsian to Eifelian in the Holy Cross Mountains (Poland). Geol. Quart., 55: 109-138.

FILIPIAK P. 2009 - Environmental differences among the Upper Silesian Block, the Małopolska Block and the Łysogóry Block (Southern Poland) during the Early Devonian. CIMP Faro'09, Portugal, September 23-24, 2009, Abstracts: 25-29.

FILIPIAK P. 2011 - Palynology of the Lower and Middle Devonian deposits in southern and central Poland. Rew. Palaebot. Palynol., 166: 213-252.

FILONOWICZ P. 1961 - Mapa geologiczna regionu świętokrzyskiego bez utworów czwartorzędowych według zaktualizowanych materiałów do Przeglądowej Mapy Geologicznej Polski, wydanie B 1:200 000. Wyd. Geol., Warszawa.
JAKUBOWSKA L. 1968 - Stratygraficzno-palynologiczne badania osadów dewonu dolnego z wierceń w Górach Świętokrzyskich (wierc. Zaręby 2, Wszachów 3, Poręba 2). Nar. Arch. Geol., PIG-PIB, Warszawa.

JAKUBOWSKA L. 1971 - Orzeczenie dotyczące prób z osadów dewońskich regionu kieleckiego Gór Świętokrzyskich. Nar. Arch. Geol., PIG-PIB, Warszawa.

JAKUBOWSKA L. 1972 - Analiza mikroflorystyczna osadów dewońskich w Górach Świętokrzyskich. Nar. Arch. Geol., PIG-PIB, Warszawa. JAKUBOWSKA L. 1974 - Stratygrafia dewonu na podstawie badań mikrosporowych $\mathrm{w}$ otworach wiertniczych regionu kieleckiego Gór Świętokrzyskich (wierc. Borków 1, Borków 2, Cedro 3, Dąbrowa 5, Zdobiec 1). Nar. Arch. Geol., PIG-PIB, Warszawa.

KARDYMOWICZ I. 1960a - Tufity z Barczy koło Zagnańska. Kwart. Geol., 4: 597-607.

KARDYMOWICZ I. 1960b - O seladonicie z Barczy w Górach Świętokrzyskich. Kwart. Geol., 4: 609-618.

KOWALCZEWSKI Z., TURNAU E. 1997 - Nowe dane o skałach paleozoicznych z okolic Klonowa i Bostowa w Górach Świętokrzyskich. Pos. Nauk. Państw. Inst. Geol., 53: 116-118.

ŁOBANOWSKI H. 1971 - The Lower Devonian in the western part of the Klonów Belt (Holy Cross Mts), Part I - Upper Emsian. Acta Geol. Pol., 21: 629-687.

ŁOBANOWSKI H. 1981 - Bukowa Góra, kamieniołom; piaskowce dewonu dolnego. [W:] Przewodnik 53. Zjazdu Pol. Tow. Geol., Kielce, 6-8 września 1981: 249-255.

ŁOBANOWSKI H. 1990 - Lower Devonian terrains of clastic deposition in Poland and their affinities to other European Devonian Palaeogeographic-facial provinces. N. Jb. Geol. Palänt. Monatsh., 7: 404-420.

ŁOBANOWSKI H., MICHNIAK R. 1960 - New data on the Lower Devonian pyroclastic series of the Klonów Ridge (Holy Cross Mts). Bull. Pol. Acad. Sci., Sér. Sci. Géol. et Géogr., 8: 53-59.

MALEC J., TURNAU E., ZBROJA S. 1990 - Dewon dolny w profilach otworów wiertniczych Goleniawy IG 1 i Lekomin IG 1. Kwart. Geol., 34: 784-785.

MAŁKOWSKI S. 1954 - O przejawach wulkanizmu w dziejach geologicznych Gór Świętokrzyskich. Acta Geol. Pol., 4: 1-52.

RACKI G., NARKIEWICZ M. 2006 - Polskie zasady stratygrafii. Państw. Inst. Geol., Warszawa.

STREEL M., HIGGS K., LOBOZIAK S., RIEGEL W., STEEMANS P. 1987 - Spore stratigraphy and correlation with faunas and floras in the type Marine Devonian of the Ardenne-Rhenish regions. Rev. Palaeobot. Palynol., 50: 211-229.

TARNOWSKA M. 1995 - Jednostki litostratygraficzne dewonu dolnego Gór Świętokrzyskich i ich korelacja. [W:] Malec J. (red.), Korelacje litostratygraficzne, biostratygraficzne i geochemiczne utworów dewonu w Górach Świętokrzyskich. Nar. Arch. Geol., PIG-PIB, Warszawa.

TARNOWSKA M. 1999 - Schemat dewońskiego wulkanizmu piroklastycznego w Górach Świętokrzyskich. [W:] X Konferencja Sozologiczna. Geologia i sozologia w regionie świętokrzyskim u schyłku XX wieku, Kielce: $43-54$.

TURNAU E. 1994 - Opinia na temat pozycji stratygraficznej utworów z odwiertów i odsłonięć: Kielce, Dyminy 2, Zdobiec 1, Modrzewie 4 na podstawie badań palinologicznych. Arch. Inst. Nauk. Geol. PAN, Kraków.

TURNAU E. 1995a - Opinia dotycząca pozycji stratygraficznej utworów dewonu dolnego z 8 otworów wiertniczych z Gór Świętokrzyskich. Arch. Inst. Nauk. Geol. PAN, Kraków.

TURNAU E. 1995b - Wyniki badań mikrosporowych w osadach dewonu $\mathrm{z}$ otw. Modrzewie 2A i Modrzewie 4. [W:] Malec J. (red.), Korelacje litostratygraficzne, biostratygraficzne i geochemiczne utworów dewonu w Górach Świętokrzyskich. Nar. Arch. Geol., PIG-PIB, Warszawa. TURNAU E., TARNOWSKA M. 1997 - Obecność zigenu (pragu) i emsu koło Kielc. Pos. Nauk. Państw. Inst. Geol., 53: 154-155.

URBAN J. 1980 - Opracowanie projektowe rezerwatu przyrody nieożywionej Barcza. Arch. Reg. Dyr. Ochr. Środ., Kielce.

WRÓBLEWSKI T. 1975 - Rozpoznanie geologiczne złóż piaskowców dolnego dewonu w rejonie Bodzentyna w Górach Świętokrzyskich. Nar. Arch. Geol., PIG-PIB, Warszawa.

WRÓBLEWSKI T. 2000 - Ochrona georóżnorodności w regionie świętokrzyskim. Wyd. Państw. Inst. Geol., Warszawa.

Praca wpłynęła do redakcji $7.08 .2018 \mathrm{r}$.

Akceptowano do druku 20.08.2018 r. 


\section{PRZEGLAD
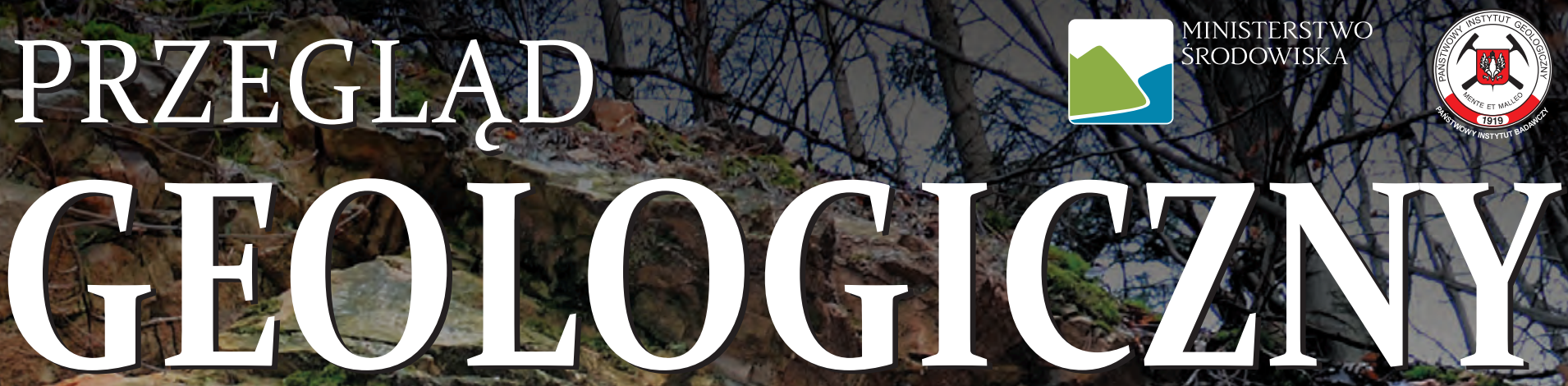

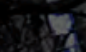

Cena 12,60 z (W tym $5 \%$ VAT) $\%$ s

TOM 66 Nr 9 (WRZESIEŃ) 2018

3ath

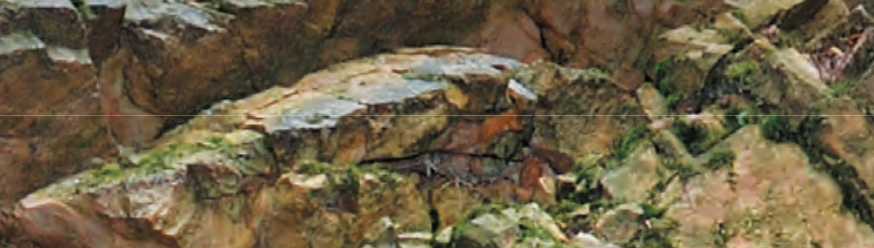

Badania zloz surowców netaliçnych pinez Panstwowy Instytut Geologicznys

Wiek poziomu tufitowego z Barczy

(Góny swiętokrysyskie)

Wtaściwości itów mio-plifoceńskich Z rejonul Bud Mszzezonowskich 
Zdjęcie na okładce: Piaskowce średnio- i gruboławicowe, dolny dewon, warstwy barczańskie - odsłonięcie we wschodnim kamieniołomie w Rezerwacie Barcza (Góry Świętokrzyskie). Zobacz artykuł Anny Fijałkowskiej-Mader i Jana Malca na str. 578. Fot. J. Malec

Cover photo: Medium- and thick-bedded sandstones, Lower Devonian, Barcza Beds - outcrop in eastern quarry, Barcza Reserve (Góry Świętokrzyskie, Poland). See article by Anna Fijałkowska-Mader and Jan Malec on p. 578. Photo by J. Malec 